GHANA JOURNAL OF DEPARTMENT OF HEALTH, PHYSICAL EDUCATION AND RECREATION, SPORTS AND DANCE (GJOHPERSD)

\author{
Volume 11, Year 2018
}

A JOURNAL OF THE DEPARTMENT OF HEALTH, PHYSICAL EDUCATION AND RECREATION (HPER)

UNIVERSITY OF CAPE COAST GHANA, WEST AFRICA 


\title{
LEGAL LIABILITY IN THE ADMINISTRATION OF SPORTS AND PHYSICAL EDUCATION PROGRAMMES IN NIGERIA SCHOOLS
}

\author{
Adelakun Kayode \& Uzorka Beatrice \\ Department of Physical \& Health Education \\ Federal College of Education Technical \\ Omoku, Rivers State, Nigeria. \\ jakpub@yahoo.com \\ +23408035005830
}

\begin{abstract}
Sport administrators, sport coaches and physical educators in schools are expected to be well grounded in their profession. They are expected to work within their limit and minimize occurrence of accidents and severity of injuries if not out rightly eliminate it in physical education and sport settings. More than any other subject in the school curriculum, physical education and sport programmes expose students to risky situations, which sometimes result in accidents and injuries. These may sometimes result in litigations against the physical education teacher or the school authority, and if found guilty, a teacher may pay heavy damages for his negligence and may also lose his job. School authority may also be found to be vicariously liable with the burden of payment of heavy compensation. This paper presents an exposition of legal issues in the administration of physical education and sports in Nigeria schools. While this paper is not attempting to make an attorney out of a physical educator or sport administrator, the paper adopted a theoretical approach to explaining the need to be conscious of what
\end{abstract}


Legal Liability in the Administration of Sports and Physical Education programmes in Nigeria Schools

is legally expected of a professional physical educator or a sport coach because parents and students in Nigeria are becoming more legalistic nowadays. This paper explains the roles of professionals in the field of sports and physical education in preventing accidents and injuries, so as to reduce situations that can lead to litigation. The paper also tries to awaken the consciousness of the professionals on the defenses they can put up in case of any litigation emanating from the discharge of their duties and the expected standards of care, which a physical educator must demonstrate in a physical education lesson or during sport outing.

Keywords: sport, litigation, liability, administration, negligence, injury. 


\section{Introduction}

Legal liability is a state of being responsible for an injury or harm caused to another person according to the law. Bucher and Krotee (2002) described liability as the condition of affairs that gives rise to an obligation to do a particular thing to be enforceable by court action. William (2006) simply puts liability as a state of being legally responsible for the harm one causes another person. Babalola and Alayode (2012) defined legal liability as one taking responsibility for an act of omission or commission. A physical educator or sport manager is liable when he/she fails to carry out his obligation or responsibility professionally and such failure results in harm to another person most especially his student or athletes. If any harm is done to a student or an athlete under the leadership of a physical education teacher, that teacher is liable, and such an individual athlete or student may seek redress in a law court and damages may be awarded against the teacher and, or the school.

Accidents and injuries are common in the field of physical education. The inherent hazards in physical education classes and sports settings make physical education teacher and coaches to be prone to litigations than any other subject teacher in the school environment. Spengler and Hronek (2011) stated that sports contain all the elements necessary to make those activities subject to accidents and subsequent lawsuits. Sport activities generally are competitive and fast-paced in which body contact is hardly avoidable in many competitive situations. Sports and physical education settings involve movements where there can be falls or collisions; it involves the use of equipment, some of which are dangerous if not properly handled and the use of facilities like swimming pool and others make the threat of legal entanglements to be more in physical education classes more than any other in a school setting. Allen (2013) states:

The thing that exposes physical education teachers and coaches to more liability than classroom teacher is 'movement'. The amount of student movement in (other) classroom is 
Legal Liability in the Administration of Sports and Physical Education programmes in Nigeria Schools

limited; therefore the classroom teacher does not have the liability exposure of a physical education teacher or a coach. Add to that fact, PE teachers and coaches deal with many students moving at the same time. Students also have to mix their movements with the use of projectiles like balls, javelin, shot put, discus etc ... and various instruments that propel these projectiles to high speed like bats, rackets, golf clubs etc, which can cause injury...

Therefore the chances of students and athletes sustaining injury are higher in physical education and sport setting. Injury can occur in the field of play, play grounds, swimming pools, gymnasium, and golf courses or even from accidents on the way to match venues, camping or other outdoor activities. Physical or psychological injury that may arise from accidents in physical education and sport settings makes physical education teacher or coaches to be susceptible to litigation. All physical education and sport programmes involve risk taking. This implies that there could be accidents when taking part in the programmes, but preventable efforts humanly possible must be seen to have been taken by teachers or coaches. Hence, it is necessary for them to avoid accident-provoking circumstances at all times during the course of their duties to avoid litigation. Besides, it should be borne in minds that in case of litigation emanating from injuries in physical education and sport settings, the court is not looking for all injuries to be avoided. The court is looking for a teacher who is reasonably prudent in teaching and overseeing the activities of his students There is an increasing awareness about rights of pupils and students in educational institutions globally. Parents and students are taking teachers, school authority and even government to court to seek redress if they noticed infringement on their rights. William (2006) observed that in recent years, negligence suits against teachers, coaches, athletic trainers, school officials and physicians arising out of sport injuries have increased both in frequency and in the amount of damages awarded. This is happening because 
students and parents of students in schools are becoming more sophisticated about their rights. Also, the number of qualified lawyers who can handle cases is ever increasing, thus individuals have easy access to lawyers who can institute cases for them sometimes without cost. More importantly, there is a gradual erosion of the doctrine of sovereign or governmental immunity, which stipulates that 'a king could do no wrong'. This principle used to protect government agents. Many teachers and school authorities have been hiding under the protection of this principle since they are representing the government. However, Bucher and Krotee (2002) stated that governmental immunity has been modified, abrogated or subjected to exception by either legislation or judicial decision. This has made some students to sue and claim damages for injuries they sustained as a result of negligence of the teacher or the school authority.

In Nigeria, litigation against physical education teachers or coaches is not yet very popular. There are not many concluded court cases in this regard. Perhaps, people who suffer harm don't go to court because of the cost of hiring attorneys, fear, and ignorance of their rights or it could be because of the culture of brotherhood that permeates the entire society. These may make students who suffered wrong from negligence of their schools and teachers not to seek redress or compensation. One fact cannot be denied, students and student-athletes sustain injuries which could be avoided in physical education and sport settings in schools in Nigeria. In ideal situations, some of those accidents in the field of sport are good causes for litigation. The fact that students hardly seek redress does not mean that students don't sustain injuries as a result of carelessness of their physical education teacher or coach. Pupils in primary schools suffer injuries in physical education classes taught mostly by unqualified teacher. The teacher, school authority and the Ministry of Education are liable in this type of situation if pupils sustained injuries in physical education classes taught by unqualified teachers. Students in Nigeria schools often sustain injuries during practice for Inter-House sport and other sporting competitions. Sometimes, students sustain injuries from the practice of games they have not been adequately or 
Legal Liability in the Administration of Sports and Physical Education programmes in Nigeria Schools

progressively taught how to play. Students sustain injuries from faulty equipment; students-athletes get involve in vehicular accidents on their ways to competition venues. These and many other areas may put coaches and physical educators at risk of litigation.

One fact cannot be taken out of Nigeria today - Nigerians are becoming more litigious than before. Parents and students are becoming aware of their rights on a daily basis. Nigerians no longer hesitate to press charges against anybody who wronged them. The number of qualified lawyers in Nigeria is increasing on yearly basis. This is bringing courts nearer to people than what we had two or three decades ago. Besides Spengler and Hronek (2011) stated that highway billboards and newspaper legal adverts encourage and entice people to file suits. The authors further stated that advertising legal services with bold headlines that generally states: INJURED? IT COST YOU NOTHING TO TALK TO US, WE ARE PAID ONLY IF YOU COLLECT is a tempting statement for a student or parent that has high medical bill to pick or that is angry about the accident. Lawyers were not known to advertise themselves in the past, but nowadays, signposts bill boards and other forms of advertisements by lawyers to get noticed are very prominent in the streets. Also there are free legal services for vulnerable groups in Nigeria. An aggrieved student can explore this and institute legal case against a physical education teacher. Moreover, Internet has turned the world into a global village, as a result of this, students and parents have access to how similar problems were resolved in other countries and this may prompt them to assert their rights or seek redress in law courts. To this end, physical educators, coaches, sport administrators and other stakeholders in sport should wake-up and always do what is professionally right in the course of discharging their duties. Nigeria is changing and so also the attitude and the propensity to sue is changing. When people begin to have easy access to courts in Nigeria, they will be more inclined to sue. What was overlooked in the past may be a source of litigation today. 
Therefore, it is obligatory on the physical educator and coaches to ensure the safety and well-being of students and athletes at all times once they are under their care. Physical educators need to abreast of development in their profession as well as how recent development in law affects their profession. Physical educators must know what the law demands of them. While this paper is not a substitute for law books or legal advice from experts, it provides an insight into areas that can give rise to ligation in physical education and sport settings and how the teacher can prevent it as well as how the defendant (the teacher/coach) can minimize the success of the plaintiff or students or student-athlete in law court

\section{The Law of Tort}

Tort is a Latin derivative from tortus or torquere which means 'twisted' 'wrong' or 'crooked'. In legal parlance, it is a legal wrong for which the law provides remedy. It is a legal wrong resulting in direct or indirect injury to another individual or to property or to one's reputation (Bucher and Krotee 2002). The law of tort is based on the legal premise that individuals are liable for the consequences of their action or inaction if such conduct results in injury to another person. Winfield cited by Keenan (1986) stated that 'tortuous liability arises from a duty primarily fixed by law: this duty is towards persons generally and its breach is redressible by an action for unliquidated damages'. This implies a civil wrong in which an individual breaches a duty owed to persons generally as fixed by law and its breach can be corrected by an action for damages. Abisoye \& Ige (2008) described a tort as a breach of a civil duty imposed by law and owed towards all persons, the breach of which is usually redressed by an award of unliquidated damages, injunction or other appropriate civil remedy. The authors further explained that a tort is a purely civil wrong which gives rise to civil proceedings, the purpose of such proceedings being not to punish wrong doers for the protection of the public at large, but to give the individual plaintiff compensation for the damage which he has suffered as a result of the defendant's wrongful conduct. In explaining the concept of tort further, Nakpodia (2012) stated that everyone is expected to behave in a straightforward manner and 
Legal Liability in the Administration of Sports and Physical Education programmes in Nigeria Schools

when one deviates from the straight path into crooked ways, he has committed a tort. Hence, tort is a conduct which is twisted or crooked and not straight. This law is always applied when a physical educator or a coach performs his duty in a twisted, crooked and an unprofessional way that results in harm to his students or other persons. Physical educators are expected to conduct their duties without injuring their students or athletes. However, if a student sustained injury as a result of the negligent act of the physical educator, he may be required by a court to pay money usually called damages to the injured student so that he would ultimately suffer pain from his action. There is likelihood of the law of tort to catch up with a physical educator or a coach who is ignorant of the law or who ignores the rules.

The essence of law of tort of tort is in many folds, especially as it affect physical education and sport settings. The law provides a channel for compensating victims of injury and loss (Abisoye and Ige 2008). A student who sustained injury as a result of carelessness on the part of the teacher or coach may be compensated for the injury sustained. It serves as deterrence for other people or coaches. Other teachers, coaches and stakeholders would know their limit and expected behavior in similar situation. Law of tort provides an avenue for vindication. A physical educator or a coach who regards himself innocent or not liable can be vindicated by a court. Generally, law of tort provides punishment for a wrongful conduct in form of damages or fines.

A coach or physical educator may find himself entangled with litigation for various reasons. It could be because of his ignorance of the law, which is never an excuse. It could be because of failure to do what he is expected to do or doing what he supposed not to do. A physical educator could also be charged for ignoring the law. Bucher and Krotee (2002) stated that 'failure to inspect facilities and equipment on a regular basis, failure to properly repair faulty equipment, omitting warning and hazard signs or failing to issue warning statements during strenuous and potentially hazardous activities are domains of litigation that have produced individual awards in excess of $\$ 1$ million'. Therefore a coach or physical 
educator should be wary of acts that could lead to litigation during the course of his duties.

\section{Tort of negligence in Physical education and sport settings}

The aspect of law of tort that mostly applies to the primary liability of a physical educator or a coach is negligence. William (2006) stated that when an athletic trainer is sued, the complaint typically is for the tort of negligence. Allen (2013) equally stated that the law that applies to the primary liability exposure of a P.E teacher or a coach is negligence. In ordinary language, negligence may simply mean not done intentionally (Keenan 1996). To a layman, negligence may mean carelessness. Legal Services Commission of South Australia cited by West (2014) described negligence as doing or failing to do something that a reasonable person would or would not do in a certain situation and which causes another person damage, injury or loss. Newnham (2000) stated that negligence is part of tort law and deals with grievances between individuals where one party has suffered as a result of something the other party did or did not do. The author futher stated that the purpose of negligence is to receive compensation for the injury sustained. Baron Alderson in Blyth v. Birmingham Waterworks Co. cited by Keenan (1996) States:

Negligence is the omission to do something which a reasonable man guided upon those considerations which ordinarily regulate the conduct of human affairs would do, or something which a prudent and reasonable man would not do.p385

In a simple language negligence is a conduct that falls below the standard expected of a prudent person. It is a conduct that that results in the creation of an unreasonable risk or harm to others. When a physical educator or a coach does something that a reasonably prudent physical educator or person would not do or he fails to do something that a reasonably prudent physical educator or person would do under the same circumstances or similar he 
Legal Liability in the Administration of Sports and Physical Education programmes in Nigeria Schools

may be guilty of negligence. Technically, negligence in physical education and sport settings may emanate from nonfeasance which can also be referred to as an act of omission. This happens when a Physical educator fails to perform a legal duty. For instance, if a physical educator fails to provide spotting during gymnastic activities or if he fails to remove faulty equipment during the class and a student sustained injury as a result of his failure to do what is right or if he fails to refer an injured person to the hospital or clinic. It could also emanate from malfeasance (act of commission) when a physical educator does what is not legally his duty to do. For instance, a physical educator is not legally permissible to give injection to an injured athlete, if he does, he may be sued. Lastly, legal wrong in sport or physical education setting could emanate from misfeasance, when a physical educator improperly does what he is legally required to do. For instance if a physical educator fails to follow progression in the teaching of a sport skill and an injury occur to a student or if he administered a first aid procedure wrongly, he may be liable.

The tort of negligence in physical education and sport settings has three main ingredients which the student or athlete (plaintiff) must prove before the teacher or coach (defendant) could be found guilty. First, there must be duty to care which the defendant owes the plaintiff. Second, there must be breach of duty owed by the defendant, and third, there must be injury or loss as a result of the breach of duty by the defendant. These three elements must be proved, failure to prove one, means that the physical educator or coach is not guilty of negligence. Negligence is not actionable per se (Keenan 1996), it is what comes out of the negligent act. Capel (2002) stated that no claim will succeed in respect of what is strictly an accident. This implies that after taking all the precautions and acting professionally in every situation, a teacher cannot be guilty of what is beyond his control. 


\section{Duty to care}

As long as a student is under a physical educator or a coach, the teacher has a duty to care for that student. He is under obligation to give physical, emotional and mental care to the student. Bucher and Krotee (2002) stated that a physical educator or coach has a professional duty to the students with whom he or she works. Mebradu (2011) described duty of care as a duty or service aimed at protecting the interest of others from wrongful act or tort of negligence. The physical educator assumes the responsibility for physical and psychological well-being of the students immediately they leave normal classroom setting for physical education class until the students return to the normal classroom for other subjects. Whether the physical education class will take place, in the field, indoors or swimming pool, teacher's standards of care are expected to conform to what a superior parent would do. A superior parent is the one who has both the knowledge of child parenting as well as the technical knowledge of the classroom situation which his child is subjected to. Hence he is said to be a superior parent. While the doctrine of in loco parentis is a common principle known to teachers, it must be noted that the legal responsibility of a physical education teacher in many respects go beyond that of a parent. The standard of care owed by teacher is much higher than the standard of a reasonable parent. A coach or physical educator is a superior parent because he combines the skill of parenting with that of a professional physical educator. A parent may not be fully aware of inherent danger in a sport or physical exercise, but a physical educator is expected to know and insulate his student from such danger. Hence supra parental care is expected of a physical educator to his students. Duty of care is not limited to classroom situation, it is extended to outdoor pursuits like camping and sporting competitions outside the school. 
Legal Liability in the Administration of Sports and Physical Education programmes in Nigeria Schools

\section{Breach of duty}

This is another element of negligence that must be proved by the plaintiff. After it has been established that a physical educator has a duty of care, the court determines whether there was a breach. A breach of duty of care occurs when a physical education teacher fails to meet the required standard of care or when his conduct falls below the expected standard on the occasion. The standard required is a legal standard of acting as a reasonable man (Keenan 1986). The standard required is not that of a particularly conscientious man but that of the average prudent man in the eyes of the court (Daniels v. White and Sons cited by Keenan 1986). In physical education and sport settings there are standards which an expert in the field must observe. The environment in which a physical education lesson is taking place must be safe. This includes the playing arenas and the equipment to be used. They must be appropriate to the age and level of the students. Any damaged equipment should not be used. The standard of care also involves adequate supervision of students. This includes the ability of the teacher to discipline, organize and observe his students. He is expected to be at vantage position that will make him to discern faulty movements that could result in injuries. Students must never be left unsupervised at any time even when the teacher has a visitor or his attention is needed by other person even for split seconds. Standard of care also involves quality instruction as well as teaching progression. Capel (1997) stated that a physical educator or coach must know specific rules for the activity, warn students of particular danger and set up safe routines with pupils and use appropriate lesson plans. Physical activities must be taught according to the age and ability of the students. A student who missed a previous practical class should not be allowed to join the rest of the class until he has mastered the skills taught in the previous lesson. Failure of a physical educator or a coach to observe these standards may jeopardize the safety of students and the teacher will be liable.

For instance, in Devon Hussack vs Chilliwack School District cited by Gervais (2010), the Supreme Court of British Columbia held that the Chilliwack School District was liable for 
the injury sustained by a student in his Grade 7 school year while playing field hockey in physical education class. The student was a chronic absentee who had missed over one-third of the school year. He had also missed the entire three-week long field hockey unit at the time of the accident. A pass in physical education was mandatory for the student to be promoted to the next grade. This student had background knowledge in ice and floor hockey but no experience in field hockey. In a bid to assist the student, the teacher felt Devon could bring his experience in ice and floor hockey to play so that he can be promoted to the next class. He allowed him to join the class and played. The teacher gave adequate instructions and emphasized the rules of field hockey again to the students before they started to play. Unfortunately during play, while Devon was trying to charge from the back of another player (which was against the rule of the game) he was struck in the nose and he was immediately taken to the hospital. There were complications but no brain injury. The student later sued the school and the teacher for negligently failing to progressively teach and coach him in the necessary skills needed to play field hockey. After a long argument from both the plaintiff and the defendants, the court found that the actions of the physical education teacher were unreasonable because he failed to progressively train and coach the student in field hockey. The court ruled that the student lacked the necessary 'skills' building blocks' that were put in place in previous lessons when Devon was absent. Thus the teacher breached his duty to care and the school was also liable. The student was awarded \$1,365,000 (i.e $\$ 491,400,000$ at today's exchange rate of $\mathrm{N} 360 / \$ 1$ in Nigeria) in damages. This decision is noteworthy for physical educators. Even if a student is at the risk of failing examination, safety of student must always be given priority; students must acquire necessary building-block skills. It is the duty of the teacher to protect his students first, other things like passing examinations is secondary.

\section{Injury resulting from the breach of duty}

The plaintiff must show that he has suffered some loss or injury as a result of breach of duty to care by the teacher. It is not 
Legal Liability in the Administration of Sports and Physical Education programmes in Nigeria Schools

enough to say that a student suffered an injury in a physical education class; the question to be asked is whether the injury was caused by the negligence of the teacher? Remote causes of the accident would be considered by the law court. For a teacher to be guilty of negligence, there must be direct links among the three elements. There must be a link to show that the teacher owes the student a duty and there was a breach of that duty and the breach of that duty resulted in accident which caused injury to the student. Injuries in sport and physical education settings could be physical and emotional. Therefore a student could sue a teacher for psychological damage without an sign of physical injury.

In all of these, the burden of proof in negligence usually lies on the student or plaintiff, except where the situation is so glaring or 'the thing speaks for itself' (res ipsa loquitur). Even with the principle of res ipsa loquitur Keenan (1986) stated that just because the principle of res ipsa loquitur applies, it is not certain that the plaintiff will succeed because the court is not bound to find the defendant negligent if the defendant is able to prove how the accident happened and that he was not negligent.

\section{Defenses against negligence}

No sport coach or physical education teacher would like accident to occur in his class. In fact coaches and physical educators hate to see their athletes and students sustained injury. Sometimes accidents are inevitable, and injuries from accidents in sport are common. Athletes, students or their parents may want to claim damages for injuries sustained during the course of the programme. Bucher and Krotee (2002) stated that damages for negligence are compensatory or money to pay medical bill, rehabilitation, and other expenses related to the incident. To avoid or reduce the payment of damages, a physical educator must put up a spirited effort to defend himself through a sound lawyer, otherwise he should go for out of court settlement if he's convince that he is guilty so as to avoid undue stress and cost of attorney. There are many ways in which the physical educator can defend himself. Some of these include: 
Contributory negligence. Students and athletes have duty to be prudent and act reasonably for their own safety. Sometimes when accident occurs, both student and teacher have been negligent and this raises the doctrine of contributory negligence. Kodilinye cited by Babalola and Alayode (2012) explained contributory negligence as negligence of the plaintiff himself which combines with the defendant's negligence in bringing about the injury to the plaintiff. This implies that both the plaintiff and the defendant did not conduct themselves in a way that a reasonable or a prudent person will behave prior to the accident that caused the injury. If the plaintiff had acted reasonable the accident wouldn't have occurred or the degree of injury would have been minimal. Contributory negligence can be argued in two ways vis-a-vis: the plaintiff contributed to the accident or the plaintiff contributed to the resulting damage. Failure of a batsman to wear helmet or leg pads in cricket game after he has been instructed to do so will amount to contributory negligence if the athlete sustained injury during the course of the game, and the damages that may be awarded in the law court could be reduced. Keenan (1986) stated that a person may contribute to the damage he suffered although he is not to blame for the accident. Hence liability is apportionable between the plaintiff (student) and the defendant (teacher). However there is a caveat for coaches and physical education teachers here, a young child or minor will seldom, if ever, be guilty of contributory negligence (Jones v Lawrence, 1969 cited by Keenan, 1986).

Volenti non fit injuria (To one who is willing no harm is done). This is also known as doctrine of the assumption of risk, that is, the plaintiff has willingly assumed the risk before taking part in the physical activity and no injury is done to one who consents. Risk is present in any physical activity and sport, an athlete who willingly submitted himself to the activity should not blame his coach or teacher for the injury sustained. In sport and physical education settings, athletes must be fully aware of the risks involved so that they can make informed decisions. Once an athlete is fully aware of the risks in a sport or physical activity, and 
Legal Liability in the Administration of Sports and Physical Education programmes in Nigeria Schools

voluntarily participates in such activity or sport, he has assumed full responsibility for his action and his right has been voluntarily surrendered or waived. For instance if an athlete $\mathbf{Y}$ takes part in rugby game or boxing, he must be presumed to accept the rough tactics which are characteristics and normal part of the game, and any damage caused would not give rise to an action (Simms $v$ Leigh Rugby football club, 1969 cited by Keenan 1996).

However, Bucher and Krootee (2002) gave a warning here, that a defense of assumption of risk is valuable only when parties know of the risks, understand the nature of the risks and freely choose to incur the risk. Australian Professional LiabilityEducation (2000) cited by Newnham (2000) further cautions that "a school or parent cannot on behalf of a child contract out of a basic common law right to sue for an injury". This implies that, even if parents signed for a child to participate in physical activities, and an injury occurred, that agreement does not exempt the child who is a minor from claiming his right and a school or teacher who relied on the signed agreement by parents is extremely unlikely to succeed. In all, for the principle of volenti non fit injuria to hold, the defendant must proof that the plaintiff knew of the risk, and he must show evidence that the plaintiff agree to accept the risk. It should however be noted that Keenan (1986) stated that it does not follow that because a person has knowledge of a potential he assents to it.

Acts of God. When accident occurs from the course of nature, which has no human causation and it his beyond the foresight of the coach or physical educator, the defendant can argue for protection under acts of God. The situation is beyond human prudence or the control of the coach. Keenan (1996) stated that it is something in the course of nature so unexpected in its consequences that the damage caused must be regarded as too remote to form a basis for legal liability. In sport setting, if lightning killed or injured an athlete or student, it would be an act of God because it is beyond the control of the teacher. 
However, this argument may not hold if the coach deliberately allowed the athletes to play in an open field under storm and rains.

Sovereign immunity. A king can do no wrong. This defense is based on the principle that neither the government nor any individual who is employed by the government can be held liable for negligence. Since physical educators in public schools are employed by government they are immune from prosecution for negligent act. This argument is gradually fading out in modern day. Even government can now be sued when the right of individual is infringed. In Nigeria, a teacher should not rely on this defense.

\section{Implications for administration of physical education and sports}

Physical education and sport programmes are inherently risky; nonetheless, they are interesting parts of the school curriculum. Physical educators and coaches must pay attention to the following points which are not exhaustively listed and discussed, to reduce accidents and minimize the risk of litigations: physical educators and coaches must,

1. be familiar with the health status of the students and athletes. He must be aware of students who have special medical conditions like Diabetes, Allergies, Injuries, Heart Conditions, Epilepsy, Disability, and prudently decide whether they should take part in physical activities or not.

2. not permit injured student or athlete to continue with the activity. Request for medical clearance of a student or athlete who had been previously injured.

3. not withhold information about risks inherent in a sport from their students

4. not force any student or athlete to perform beyond his/her capacity

5. not entertain visitor or allow anybody to distract him during practical session, even if the principal needs his attention. In other words, he must not leave students unsupervised at any time. 
Legal Liability in the Administration of Sports and Physical Education programmes in Nigeria Schools

6. Properly conditioned the athletes or students through various warm-up activities before any rigorous activity.

7. ensure that equipment and facilities are proper for the activity and safe for students use at all time. Any faulty equipment must be removed and put out of use until it is fixed.

8. record accidents and injuries sustained in school's accident report sheet and report the incident to the appropriate authorities. He must also take action by sending the injured athlete to hospital for proper medical examination.

9. know the limitation of his expertise in the skill he is teaching as well as his knowledge of first aid and work within the scope of his knowledge..

10. ensure progressive teaching of practical skills and ensure that a student who missed a class should not be allowed to join the rest of the class in the next practical lesson until he has been taught the skills he missed in the previous lesson. It will be unsafe for a student to participate in a practical lesson without having the building blocks of the activity in place.

11. ensure that students wear protective equipment and make sure that the equipment are properly fitted before students engage in the activity.

12. be sure to give proper instruction and warnings to students before the commencement of the class. $\mathrm{He} /$ she must ensure that students maintain discipline at all time

13. ensure that school bus or hired vehicle conveying the students to a competition venue or camp site is in good condition

14. report accidents to the appropriate authorities immediately after the class.

There are rules and ethics that guide teaching profession. A physical education teacher should know that because of the nature of his subject, more is required from him than an average or ordinary teacher teaching any other subject. While the list of what 
a physical education teacher or a coach should do or not do as presented above is in exhaustive, a physical educator must place the safety of his students at the premium. He must be prudent, careful, insightful, attentive and discerning.

\section{Conclusion}

It is impossible to take risk out of physical activities and sport. In fact taking risk out of physical education classes and sports is tantamount to taking pleasure or fun out the activities. However, Physical education teachers and coaches have legal responsibility to ensure the safety of students under their care they are expected to act within the confine principles guiding their profession. They must provide excellent leadership that is more than a careful and reasonable parent. They must be cautious and be wise in providing guidance. They are expected to have foresight so as to notice and predict danger. Their carelessness can caused death, severe injuries or psychological trauma to students and they may severely pay for the damage done either by losing their jobs; pay severe damages or lose their reputation.

\section{References}

Abisoye, O.M. \& Ige, A.E.O. (2008). Law of tort. Abuja: National Open University

Allen, A.C. (2013). Legal Liability of physical education teachers and coaches. Retrieved on the $2^{\text {nd }}$ April, 2017 from http://www.vegaspersonalinjurylawblog.com/blog/2013/0 7.

Babalola, A.J \& Alayode A.M. (2012). Sources of legal liability among physical education teachers. International Education Studies 5(3) 193-198.

Bucher, C.A. \& Krotee, M.L.(2002) Management of physical education and sport (12 ${ }^{\text {th }}$ ed). New York: McGraw Hill

Capel, S. (1997). Learning to teach physical education in secondary school. London: Routeldge 
Legal Liability in the Administration of Sports and Physical Education programmes in Nigeria Schools

Gervais, B.L 2010). Court rules that physical education teacher was negligent in coaching field hockey. Retrieved on the $2^{\text {nd }}$ April,2017fromhttp://www.lexology.com/library/detail .aspx

John, H. (1981). Teach your own: a hopeful part for education. New York: Merloyd Lawrence.

Keenan, D. (1996). Smith and Keenan's English law $\left(8^{\text {th }} \mathrm{ed}\right)$. London: Pitman.

Mebradu, R.E. (2001). Legal principles in Nigerian Secondary school administration. In Olawolu, O.E and MadumereObike, C. (Eds) Introduction to educational management, Port-Harcourt: Informedia

Nakpodia, E.D. (2012). Legal knowledge of tort liability for teachers in the Nigerian schools. International journal of advanced legal studies and governance 3(1) 131-140.

Newnham, H.(2000). When is a teacher or school liable in negligence. Australian Journal of Teacher Education 25(1).

Spengler, J.O. \& Hronek, B.B (2011). Legal liability in recreation, sport and tourism. Urbana: Sagamore.

West, B. (2014). Safety and legal issues in physical education. Retrieved on the $2^{\text {nd }}$ April,2017 from https://prezi.com/mwncpl5zlkxq/safety-and-legal-issuesin-PE/95 .

William, P. (2006). Arnheim's principles of athletic training: a competency-based approach. New York: McGraw Hill. 